\title{
Klebsiella pneumoniae-related invasive liver abscess syndrome complicated by purulent meningitis: a review of the literature and description of three cases
}

\author{
Ruixue Sun ${ }^{1}$, Hui Zhang ${ }^{2}$, Yingchun $\mathrm{Xu}^{2}$, Huadong Zhu' ${ }^{1}$ Xuezhong $\mathrm{Yu}^{1}$ and Jun $\mathrm{Xu} \mathrm{u}^{\text {1* }}$
}

\begin{abstract}
Background: Klebsiella pneumoniae (K. pneumoniae) invasive liver abscess syndrome (ILAS) with purulent meningitis was rarely identified the mainland of China. Last winter, we received 3 cases of $K$. pneumoniae meningitis and all of them died in a short time. We report these cases in order to find the reason of high mortality and discuss effective effort to improve these patients' prognosis.

Case presentation: Three patients with uncontrolled diabetes developed live abscess and purulent meningitis. Upon admission, the clinical manifestations, laboratory result of blood and cerebrospinal fluid (CSF) and imaging examinations were compatible with K. pneumoniae ILAS which had metastasis infection of meningitis. Even with timely adequate antibiotic therapy and strict glycemic control, all of the patients' condition deteriorated rapidly and died in a short time.

Conclusion: The reason of patients' poor prognosis might be the absence of liver abscess drainage, high level of CSF protein which indicates severe inflammation and unknown special but stronger virulence factors of $K$. pneumoniae the patients' living place Zhangjiakou. Strict glycemic control, early drainage of liver abscess and appropriate antibiotic application are recommended for treating this condition, further progress on the pathogenesis and treatment of $K$. pneumoniae meningitis may help patients gain a better prognosis.
\end{abstract}

Keywords: Klebsiella pneumoniae, Meningitis, Liver abscess, Case report

\section{Background}

Over a century ago, bacterial meningitis was virtually $100 \%$ fatal [1]. Despite current antibiotics being able to clear bacteria from the cerebrospinal fluid (CSF), mortality remains approximately $25 \%$, and, even among survivors, $21-28 \%$ of patients have chronic neurologic complications $[2,3]$. Streptococcus pneumoniae is the most common bacterial cause of community-acquired meningitis in

\footnotetext{
* Correspondence: pumchxujun@126.com

${ }^{1}$ Emergency Department, Peking Union Medical College Hospital, No.1 shuaifuyuan, Dongcheng District, Beijing, China

Full list of author information is available at the end of the article
}

adults. The distribution of other pathogens, such as Neisseria meningitidis, group B Streptococcus, Haemophilus influenzae and Listeria monocytogenes, depends upon the age of the patient, their vaccination status and the regional epidemiological trends where the patient lives $[4,5]$. Besides the more common organisms listed above, Klebsiella pneumoniae (K. pneumoniae) has been reported as a cause of community-acquired meningitis in Taiwan with a mortality rate of $30-40 \%$ in patients with liver abscesses $[6,7]$. Diabetes and age $>65$ years old were independent predictors of septic ocular or CNS complications in patients with liver abscesses [8]. Besides Taiwan, in South Korea,

(c) The Author(s). 2020 Open Access This article is licensed under a Creative Commons Attribution 4.0 International License, which permits use, sharing, adaptation, distribution and reproduction in any medium or format, as long as you give appropriate credit to the original author(s) and the source, provide a link to the Creative Commons licence, and indicate if changes were made. The images or other third party material in this article are included in the article's Creative Commons licence, unless indicated otherwise in a credit line to the material. If material is not included in the article's Creative Commons licence and your intended use is not permitted by statutory regulation or exceeds the permitted use, you will need to obtain permission directly from the copyright holder. To view a copy of this licence, visit http://creativecommons.org/licenses/by/4.0/. The Creative Commons Public Domain Dedication waiver (http://creativecommons.org/publicdomain/zero/1.0/) applies to the data made available in this article, unless otherwise stated in a credit line to the data. 
K. pneumoniae was the third most common cause of community-acquired bacterial meningitis [9]. However, $K$. pneumoniae meningitis is rarely identified in other regions, including mainland China. In 2018, our emergency department received three cases of $K$. pneumoniae meningitis. These three initially presented with fever and altered mental status, and all three died within two days after admission. We report these cases in order to illustrate the early signs of $K$. pneumoniae meningitis and discuss potentially effective strategies to improve the prognosis of these patients.

\section{Case presentations \\ Case 1}

At 07:23 on June 3, 2018, we received a 39-year-old male patient in our emergency room. He came from Zhangjiakou in Hebei province, China and presented with five days of fever and three hours of altered mental status. He had a history of poorly controlled diabetes mellitus. At the time of admission, his vital signs included a body temperature of $39^{\circ} \mathrm{C}$, a heart rate of 146 beats $/ \mathrm{min}$, blood pressure of $125 / 84 \mathrm{mmHg}$, respiratory rate of 42 breaths/min, and an oxygen saturation of $99 \%$ on room air. He had a Glasgow coma scale (GCS) of E1 + V1 + M3 with nuchal rigidity on an otherwise unremarkable physical examination.

White blood cell count was $25.73 \times 10^{9} / \mathrm{L}$ with an elevated neutrophil percentage of $84.9 \%$. The concentration of C-reactive protein (CRP) was $>240 \mathrm{mg} / \mathrm{L}$, glucose was $30 \mathrm{mmol} / \mathrm{L}$, arterial blood gas (ABG) results were as follows (on $3 \mathrm{~L} / \mathrm{min}$ of oxygen via nasal cannula): $\mathrm{pH}: 7.09$, arterial pressure of $\mathrm{CO}_{2}\left(\mathrm{PaCO}_{2}\right): 9.7 \mathrm{mmHg}$, arterial pressure of oxygen $\left(\mathrm{PaO}_{2}\right): 141 \mathrm{mmHg}, \mathrm{HCO}_{3}: 2.8$ $\mathrm{mmol} / \mathrm{L}$, lactic acid: $3.9 \mathrm{mmol} / \mathrm{L}$, liver and renal function tests were within normal limits. Alb:39 g/L, PCT:2-10 $\mathrm{ng} / \mathrm{ml}$. Two sets of peripheral blood cultures were obtained (and were negative). Head and abdominal computed tomography (CT) scans demonstrated diffuse cerebral edema and possible brain and liver abscesses (see Fig. 1).

The patient next underwent a lumbar puncture examination. The opening pressure was $150 \mathrm{~mm} \mathrm{H}_{2} \mathrm{O}$. CSF appeared yellow and purulent, revealing a 178,640 $\times 10^{6}$ / $\mu \mathrm{L}$ white blood cell count with a multinucleated cells percentage of $86.2 \%$, protein $32.41 \mathrm{~g} / \mathrm{L}$ and glucose 10.2 $\mathrm{mmol} / \mathrm{L}$. CSF was submitted for Gram staining and bacterial culture. The above findings led to the diagnoses of purulent meningitis, sepsis, diabetic ketoacidosis (DKA), as well as (possible) brain and liver abscesses. Meropenem $2 \mathrm{~g}$ every $8 \mathrm{~h}$ combined with vancomycin $1 \mathrm{~g}$ every $12 \mathrm{~h}$ were given intravenously. Due to the loss of spontaneous breathing, mechanical ventilation was started. Intensive care was begun and his DKA was treated. However, further invasive examinations (e.g. brain or liver abscess aspirations) were deemed too dangerous for him. At 11:41, the patient was transferred to the Emergency Department's Intensive Care Unit (EICU).

By June 4, the patient's condition had not improved. His body temperature fluctuated between $35.3^{\circ} \mathrm{C}$ and $39.5^{\circ} \mathrm{C}$. His blood pressure dropped to $91 / 64 \mathrm{mmHg}$ while the pulse rate rose to 142 beats/min. Norepinephrine was pumped venously to maintain a mean arterial pressure $(\mathrm{MAP})>65 \mathrm{mmHg}$. Pupils were bilaterally dilated at $3 \mathrm{~mm}$ 's with a slow light reflex, a GCS score of $\mathrm{E} 1+($ Ventilated $)+\mathrm{M} 1$. Based on his worsening situation, emergency bedside lateral ventricular drainage was performed. During the operation, his cerebrospinal fluid was examined again, demonstrating a white blood cell count of 19,054 cells $/ \mu \mathrm{L}$ with a multinucleated cells ratio of $78.9 \%$, protein of $1.06 \mathrm{~g} / \mathrm{L}$ and a glucose level of 0.1 $\mathrm{mmol} / \mathrm{L}$. After the operation, his intracranial pressure was consistently over $330 \mathrm{mmH}_{2} \mathrm{O}$ while undergoing continuous renal replacement therapy along with a maximal dose of mannitol.
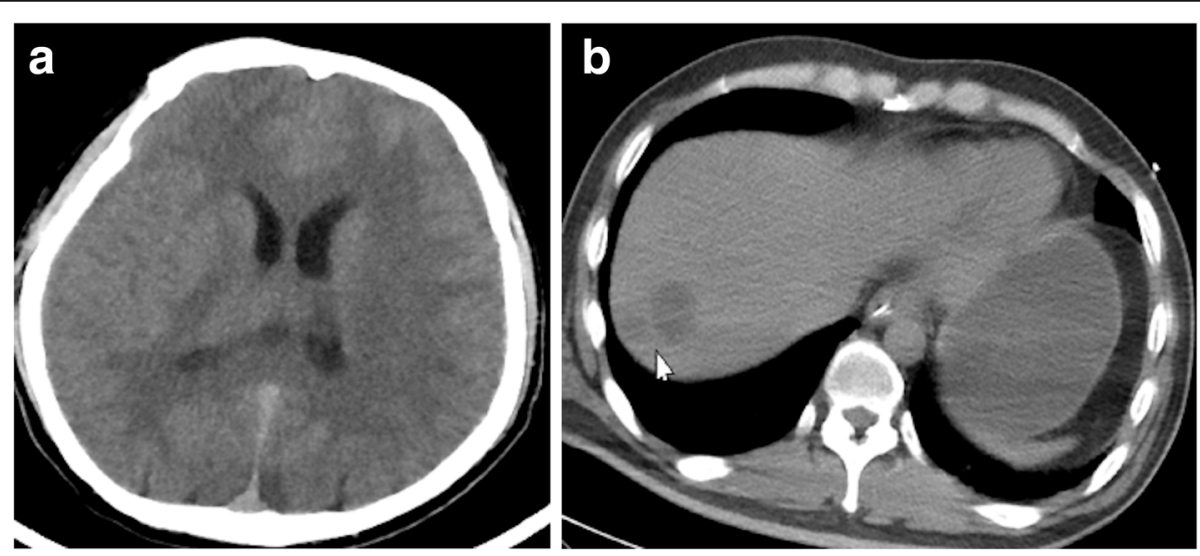

Fig. 1 a: Head CT scan showed diffuse cerebral edema; b: Abdominal CT scan demonstrating an area of abnormal attenuation measuring 24 $\mathrm{mm} \times 19 \mathrm{~mm}$ in the right lobe of the liver, suggestive of a single abscess 
K. pneumoniae was isolated from the patient's cerebrospinal fluid and was found to be sensitive to all tested antibiotics including meropenem. However, the patient's vital signs deteriorated, and he eventually died of cardiac arrest later on June 4.

\section{Case 2}

A 49-year-old woman was admitted to the emergency department of our hospital at 14:00 on July 3, 2018 because of fever and "twitching" for the past three days. She was born and currently lived in Zhangjiakou city of Hebei Province, she had a history of untreated diabetes mellitus and hypertension. At the time of admission, the patient was found to have intermittent convulsions and was unable to cooperate for a physical examination. Her temperature was $38^{\circ} \mathrm{C}$, pulse rate was 152 beats $/ \mathrm{min}$, respiratory rate 39 breaths/min, blood pressure was 158/ $88 \mathrm{mmHg}$, and her oxygen saturation was $92 \%$ on $3 \mathrm{~L} /$ min of oxygen via nasal cannula.

The patient's white blood count was $24.87 \times 10^{9} / \mathrm{L}$ with an elevated neutrophil percentage of $91.4 \%$, a hemoglobin of $148 \mathrm{~g} / \mathrm{L}$ and a platelet count of $108 \times 10^{9} /$ L. The CRP was $242 \mathrm{mg} / \mathrm{L}$, glucose was $42.4 \mathrm{mmol} / \mathrm{L}$. Arterial blood gas results were as follows (on $3 \mathrm{~L} / \mathrm{min}$ oxygen via nasal cannula): $\mathrm{pH}$ of $7.09, \mathrm{PaCO}_{2}: 9.7$ mmHg, $\mathrm{PaO}_{2}: 141 \mathrm{mmHg}, \mathrm{HCO}_{3}: 2.8 \mathrm{mmol} / \mathrm{L}$, lactic acid: $3.9 \mathrm{mmol} / \mathrm{L}$, creatinine $125 \mu \mathrm{mol} / \mathrm{l}$, Urea 13.9 $\mathrm{mmol} / \mathrm{l}$, other liver and kidney function testing was normal. The patient's procalcitonin level was $>10 \mathrm{ng} / \mathrm{ml}$. Head CT scans revealed bilateral basal ganglia hemorrhages and a subarachnoid hemorrhage. Abdominal CT scan demonstrated a possible liver abscess (Fig. 2). Puncture examination showed the intracranial pressure was $>330 \mathrm{~mm} \mathrm{H} 2 \mathrm{O}$. CSF was pale red and purulent, and revealed $4263 \times 10^{6} / \mathrm{L}$ white blood cells $/ \mu \mathrm{L}$ with multinucleated cells ratio of $43.1 \%$, protein $8.82 \mathrm{~g} / \mathrm{L}$ and glucose $0.6 \mathrm{mmol} / \mathrm{L}$.
The patient was diagnosed with purulent meningitis, septic shock, cerebral hemorrhage, subarachnoid hemorrhage, DKA and a probable liver abscess. The patient was intubated for airway protection and mechanical ventilation was begun. Meropenem $2 \mathrm{~g}$ every $8 \mathrm{~h}$ was given intravenously, and lateral ventricular drainage was performed at 12:00. After the operation, the patient's condition did not improve, and she died that afternoon due to cerebral herniation.

Two days later, blood, sputum and cerebrospinal fluid cultures all grew $K$. pneumoniae (sensitive to all the tested antibiotics including Meropenem).

\section{Case 3}

A 62-year-old male also from Zhangjiakou city of Hebei Province with a history of uncontrolled diabetes mellitus was admitted to the emergency department after he developed confusion for the past $11 \mathrm{~h}$. Two days ago, the patient complained of a fever and vomiting. The patient was seen at a different local hospital, but his condition worsened. On arrival to our hospital, his initial vital signs were: body temperature, $37^{\circ} \mathrm{C}$, heart rate 119 beats/min, blood pressure, $159 / 126 \mathrm{mmHg}$, respiratory rate, 32 breaths/min, and oxygen saturation $92 \%$ on air. His physical examination was significant for a GCS of 5 $(\mathrm{E} 1+\mathrm{V} 1+\mathrm{M} 3)$.

His white blood count was $12.39 \times 10^{9} / \mathrm{L}$ with an elevated neutrophil percentage of $92.8 \%$, hemoglobin $165 \mathrm{~g} /$ $\mathrm{L}$ and a platelet count $25 \times 10^{9} / \mathrm{L}$. ABG results were: $\mathrm{pH}$ 7.28, $\mathrm{PaCO}_{2}: 24.1 \mathrm{mmHg}, \mathrm{PaO}_{2}: 89.3 \mathrm{mmHg}, \mathrm{HCO}_{3}$ : $10.9 \mathrm{mmol} / \mathrm{L}$, lactic acid: $3.4 \mathrm{mmol} / \mathrm{L}$, CRP was $>160$ $\mathrm{mg} / \mathrm{L}$, procalcitonin $>100 \mathrm{ng} / \mathrm{ml}$, blood glucose was 24.1 $\mathrm{mmol} / \mathrm{L}$, alanine transaminase was $139 \mathrm{U} / \mathrm{L}$, total bilirubin/direct bilirubin were 62.0/31.4umol/L, creatinine was $274 \mathrm{umol}$, and urea was $22.79 \mathrm{mmol} / \mathrm{L}$. An abdominal CT scan demonstrated a single liver abscess (Fig. 3). A lumbar puncture was performed after the patient
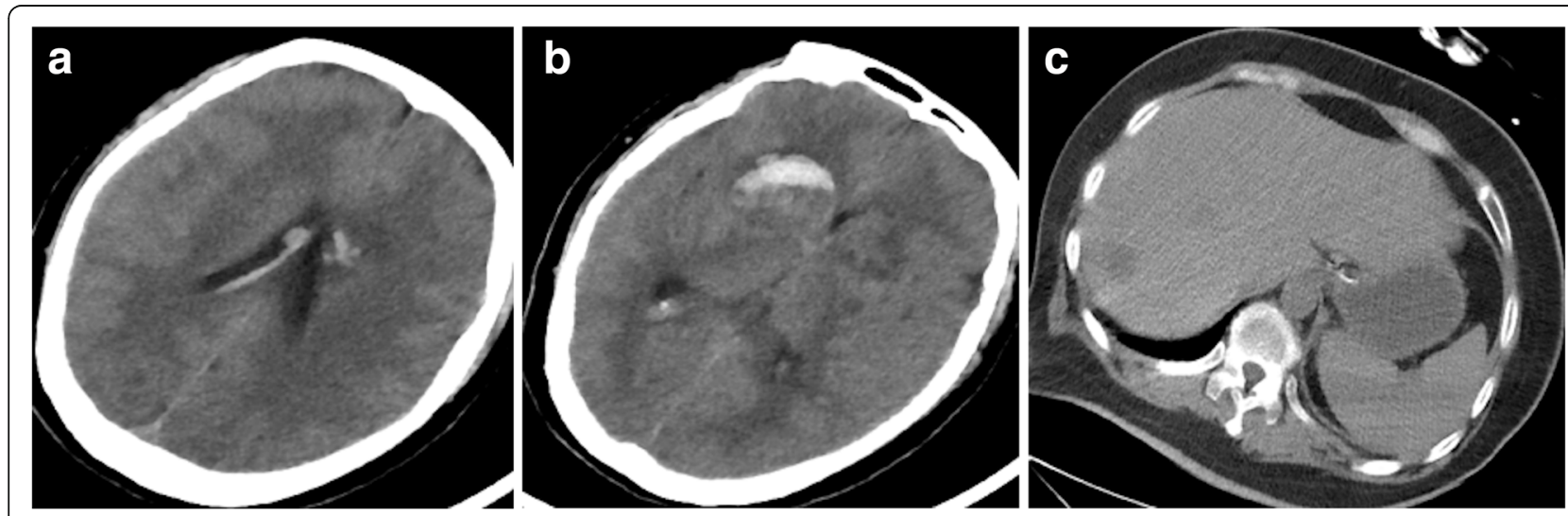

Fig. $\mathbf{2}$ a and b: head CT scan showed bilateral basal ganglia hemorrhages and a subarachnoid hemorrhage; c: Abdominal CT scan demonstrating an area of abnormal attenuation measuring $18 \mathrm{~mm} \times 14 \mathrm{~mm}$ in the right lobe of the liver 


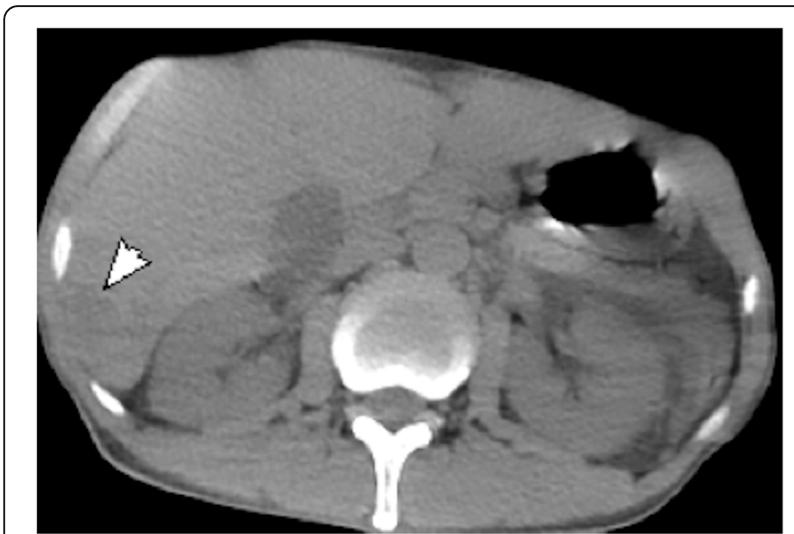

Fig. 3 Abdominal CT scan demonstrating an area of abnormal attenuation measuring $25 \mathrm{~mm} \times 19 \mathrm{~mm}$ in the right lobe of the liver

received a platelet transfusion. The opening pressure was too low to measure, and the CSF was a murky yellow and revealed $17,148 \times 10^{6} / \mathrm{L}$ white blood cells $/ \mu \mathrm{L}$ with a multinucleated cells percentage of $84.3 \%$, protein of $12.82 \mathrm{~g} / \mathrm{L}$ and a glucose of $<0.1 \mathrm{mmol} / \mathrm{L}$. The patient was diagnosed with purulent meningitis, septic shock and DKA. Meropenem $2 \mathrm{~g}$ every $8 \mathrm{~h}$ combined with vancomycin $1 \mathrm{~g}$ every $12 \mathrm{~h}$ were given intravenously and blood glucose (BG) was well controlled by insulin. However, the patient got worse and his relatives decided to withdraw care. A telephone follow-up revealed that the patient died on his way back home. Two days later, $K$. pneumoniae was isolated from his CSF and was sensitive to all available antibiotics.

\section{Discussion and conclusions}

Cases of spontaneous K. pneumoniae meningitis are rare and commonly observed in hospitalized postoperative patients. Community-acquired $K$. pneumoniae meningitis could be associated with an invasive liver abscess syndrome (ILAS). In a study, two cases $(2 / 15,13.3 \%)$ were associated with $K$. pneumoniae liver abscess. In another study from South Korea, 4 (14.8\%) of 27 patients with $K$. pneumoniae meningitis had a concomitant liver abscess [10]. But this situation is still rare, in a study, only 1 (0.9\%) of 112 patients with K. pneumoniae liver abscess had CNS involvement [11]. We reviewed the case reports and related original articles about adult communityacquired $K$. pneumoniae meningitis and found that only two cases have been recorded in the mainland of China $[12,13]$. As all three patients we received died relatively quickly, we summarized above the key points of their diagnosis and treatment and will now shift to analyzing the reasons for our patients' unfortunate outcomes.

The three patients with community-acquired K. pneumoniae meningitis in this article had poorly controlled T2DM. Meningitis was preceded by an ILAS. Accordingly, when patients with T2DM present with fever, headache, coma and confusion, a high degree of suspicion should be held for ILAS besides meningitis, including possible $K$. pneumoniae infection [14]. However, sometimes community-acquired $K$. pneumoniae meningitis appears independently without a liver abscess [13, 15-17]. Besides T2DM, other risk factors may include alcoholrelated chronic diseases, especially alcoholic cirrhosis, which is also related to ILAS $[15,16,18]$. The clinical manifestation and high leukocyte, high protein, and low glucose in each patients' CSF are often found in cases of gram-negative bacilli meningitis [19]. So, the key points for diagnosing community-acquired $K$. pneumoniae meningitis are risk factors and pathogen culture.

Currently, there are no clear guidelines for the management of $K$. pneumoniae meningitis as a manifestation of ILAS. Besides strict glycemic control, a combination of early drainage of the abscess and appropriate antibiotic application is the standard treatment for this condition [20]. The selection of antibiotics should be based on in-vitro susceptibilities and clinical response. In view of the better penetration into the CSF, large doses of third-generation cephalosporins including cefotaxime (up to $2 \mathrm{~g}$ every four hours) and ceftriaxone ( $2 \mathrm{~g}$ twice a day) are the drugs of choice for $K$. pneumoniae meningitis. Imipenem and meropenem can be given to patients when strains containing extended-spectrum betalactamases are suspected [19]. As reported in the literature, surviving patients with $K$. pneumoniae meningitis were treated with ceftazidime, ceftriaxone, cefmetazole, cefotaxime, cefepime or meropenem [13, 16, 17, 21-27]. In our cases, $K$. pneumoniae cultured from the CSF were susceptible to all the remaining antibiotics tested, but meropenem was the antibiotic chosen for all three patients, and vancomycin was also used in two of them.

Unfortunately, each patient's ending was still tragic. We noticed that the CSF protein levels in our patients $(32.41 \mathrm{~g} / \mathrm{L}, 8.82 \mathrm{~g} / \mathrm{L}$ and $12.82 \mathrm{~g} / \mathrm{L}$, respectively) were extremely high. Previous studies of neonatal bacterial meningitis showed that high CSF protein levels, which with an optimal cutoff value of $1.88 \mathrm{~g} / \mathrm{L}$ [28], were associated with poor prognosis [29-31]. The only reported case of $K$. pneumoniae meningitis who died mentioned a CSF protein of $2.34 \mathrm{~g} / \mathrm{L}$ [12]. Another study into the clinical features of patients with adult bacterial meningitis showed the CSF protein levels in such patients with good or poor outcomes were $2.18 \pm 1.47 \mathrm{~g} / \mathrm{L}$ and $4.03 \pm$ $4.19 \mathrm{~g} / \mathrm{L}$, respectively [32]. Additionally, white blood cells, immunoglobulins, and complements are normally absent in CSF, but the inflammatory response triggered by bacteria during meningitis results in increasing protein levels in the CSF which coincides with the intensity of the inflammatory response. Cytokines produced in inflammation may cause impairment of cell structure and 
organ function, thus increasing the risk of morbidity [28]. Overall then, the sky-high level of CSF protein in our patients may have foreshadowed their outcomes.

It is also noteworthy that all three patients came from Zhangjiakou city in Hebei Province. We suspect that the virulence of the $K$. pneumoniae species in this area may be particularly high. Five major virulence factors of $K$. pneumoniae are known to contribute to the pathogenesis of infection. These are the capsular serotype, hypermucoviscosity phenotype, lipopolysaccharide, siderophores, and pili. $K[10,33]$. Based on previous study, we also know that severe manifestations such as comatose mental status, septic shock, and concomitant extra meningeal infections were more common in community- acquired $K$. pneumoniae meningitis patients compared with communityacquired Streptococcus pneumoniae meningitis, and the 28 -day mortality $(44.4 \%$ versus $10.7 \% ; P=0.001)$ and inhospitable mortality $(51.9 \%$ versus $14.3 \%$; $\mathrm{P}=0.001)$ were much higher [9]. Besides the $100 \%$ mortality, all of the three patients had comatose mental status, septic shock, and live abscesses, the characters tallied with the reported study and may due to the high virulence of $K$. pneumoniae. What's worse, multidrug-resistant and hypervirulent (MDR-HV) K. pneumoniae strains had spread in the community, 13 MDR-HV strains were identified from a total of $218 \mathrm{~K}$. pneumoniae liver abscess episodes in a Taiwan Hospital [34]. Given the three cases in our study all occurred in one city in Hebei province, a future study might examine the particular virulence factors of this strain of $K$. pneumoniae.

Although liver abscess drainage has been recommended for a better clinical response [19] and hepatic resection is preferred for patients with Acute Physiology and Chronic Health Evaluation II (APACHE II) scores of $\geq 15$ [28]. In our cases, liver abscesses were less than 5 $\mathrm{cm}$, Percutaneous drainage for small liver abscess adjacent to the liver capsule can cause complications such as bleeding or peritonitis. The poor outcomes might have no business with the lack of liver abscess drainage.

In conclusion, $K$. pneumoniae meningitis is a rare cause of meningitis around the world. When patients with risk factors such as T2DM and alcoholic cirrhosis present to the emergency department with clinical features of meningitis, providers should maintain a high degree of suspicion for potential $K$. pneumoniae-related ILAS complicated by meningitis. Strict glycemic control, early drainage of liver abscesses and appropriate antibiotic application are all recommended for treating this condition. All three patients we received unfortunately died in short order, and it's uncertain whether emergent liver abscess drainage would have helped at that point given the patients' already high levels of CSF protein indicating severe inflammation. Potentially unknown virulence factors of $K$. pneumoniae in Zhangjiakou may also play a role in these patients' poor outcomes. These cases were shared with the international medical community with the hope for timely diagnoses of $K$. pneumoniae meningitis in the future and to promote progress on learning more about this bacteria's pathogenesis and treatment.

\begin{abstract}
Abbreviations
APACHE II: Acute Physiology and Chronic Health Evaluation II; BG: Blood glucose; CSF: Cerebrospinal fluid; CRP: C-reactive protein; CT: Computed tomography; DKA: Diabetic ketoacidosis; ED: Emergency Department; EICU: Emergency Department Intensive Care Unit; GCS: Glasgow coma scale; ILAS: Invasive liver abscess syndrome; K. pneumoniae: Klebsiella pneumoniae bacteria; magA: Mucoid-associated gene A; rmpA: Regulator of mucoid phenotype gene A; T2DM: Type 2 diabetes mellitus
\end{abstract}

\section{Acknowledgements}

Not applicable.

\section{Authors' contributions}

$Y C X$ and $X Z Y$ contributed to the study conception and design. Case collection and description were performed by RX S, HZ1 and JX. The first draft of the manuscript was written by RX S and JX, HZ2 revised the study design and initial manuscript, and all authors commented on previous versions of the manuscript. All authors read and approved the final manuscript.

\section{Funding}

No funding

\section{Availability of data and materials}

The datasets used and analyzed during the current study are available from the corresponding author on reasonable request.

\section{Ethics approval and consent to participate}

The Institutional Review Board (IRB) of Peking Union Medical College Hospital has reviewed the study and has determined that this is a retrospective study and the design is scientifically and is up to the ethics standards. The IRB thus approve the study.

\section{Consent for publication}

Consent for publication has been obtained from the patients reported in this article. And each patients next-of-kin have given written consent for their relative's personal or clinical details along with any identifying images to be published in this study.

\section{Competing interests}

The authors declare that they have no conflicts of interests.

\section{Author details}

'Emergency Department, Peking Union Medical College Hospital, No.1 shuaifuyuan, Dongcheng District, Beijing, China. 'Laboratory Department, Peking Union Medical College Hospital, No.1 shuaifuyuan, Dongcheng District, Beijing, China.

Received: 6 August 2020 Accepted: 9 December 2020

Published online: 06 January 2021

\section{References}

1. Schwentker FF, Gelman S, Long PH. Landmark article April 24, 1937. The treatment of meningococcic meningitis with sulfanilamide. Preliminary report. By Francis F. Schwentker, Sidney Gelman, and Perrin H. Long. JAMA. 1984;251:788.

2. Durand ML, Calderwood SB, Weber DJ, Miller SI, Southwick FS, Caviness VS $\mathrm{Jr}$, et al. Acute bacterial meningitis in adults. A review of 493 episodes. N Engl J Med. 1993;328:21-8.

3. Aronin SI, Peduzzi P, Quagliarello VJ. Community-acquired bacterial meningitis: risk stratification for adverse clinical outcome and effect of antibiotic timing. Ann Intern Med. 1998;129:862. 
4. Mai NT, Hoa NT, Nga TV, le Linh D, Chau TT, Sinh DX, et al. Streptococcus suis meningitis in adults in Vietnam. Clin Infect Dis. 2008;46:659-67.

5. $Y u$ H, Jing $H$, Chen Z, Zheng $H$, Zhu $X$, Wang $H$, et al. Human Streptococcus suis outbreak, Sichuan, China. Emerg Infect Dis. 2006;12:914-20.

6. Siu LK, Yeh KM, Lin JC, Fung CP, Chang FY. Klebsiella pneumoniae liver abscess: a new invasive syndrome. Lancet Infect Dis. 2012;12:881-7.

7. Alsaif HS, Venkatesh SK, Chan DS, Archuleta S. CT appearance of pyogenic liver abscesses caused by Klebsiella pneumoniae. Radiology. 2011;260:12938.

8. Lin YT, Liu CJ, Chen TJ, Fung CP. Long-term mortality of patients with septic ocular or central nervous system complications from pyogenic liver abscess: a population-based study. PLoS One. 2012;7(3):e33978.

9. Moon S-Y, Chung DR, Kim S-W, Chang HH, Lee H, Jung DS, et al. Changing etiology of community-acquired bacterial meningitis in adults: a nationwide multicenter study in Korea. Eur J Clin Microbiol Infect Dis. 2010;29:793.

10. Jung J, Park K-H, Park SY, Song EH, Lee EJ, Choi S-H, et al. Comparison of the clinical characteristics and outcomes of Klebsiella pneumoniae and Streptococcus pneumoniae meningitis. Diagn Microbiol Infect Dis. 2015;82:87

11. Park SY, Kim T, Kim M-C, Sung H, Kim M-N, Kim S-H, Lee S-O, et al. Ciprofloxacin treatment for cryptogenic Klebsiella pneumoniae liver abscesses. J Inf Secur. 2017 Dec;75(6):590-3.

12. Qian Y, Wong C-C, Lai S-C, Lin Z-H, Zheng W-L, Zhao H. Klebsiella pneumoniae invasive liver abscess syndrome with purulent meningitis and septic shock: A case from mainland China. World J Gastroenterol. 2016;22(9): 2861-6.

13. 何飞, 徐鹏, 陈伯柱, 王军, 张均. 成人肺炎克雷伯菌脑膜炎 1 例并文献复 习. Chin J Nerv Ment Dis. 2014; 40: 132

14. Ang CC, Yen $\mathrm{CH}, \mathrm{Ho}$ MW, Wang JH. Comparison of pyogenic liver abscess caused by non-Klebsiella pneumoniae and Klebsiella pneumoniae. J Microbiol Immunol Infect. 2004:37(3):176.

15. Orzechowska A, Lacey S, Soosay G, Melzer M. Community-acquired Klebsiella pneumoniae meningitis in an alcoholic patient with an infected pancreatic pseudocyst; a case report and review of literature. J Med Case Rep. 2007;1 116.

16. Melot B, Brisse S, Breurec S, Passet V, Malpote E, Lamaury I, et al. Community-acquired meningitis caused by a CG86 hypervirulent Klebsiella pneumoniae strain: first case report in the Caribbean. BMC Infect Dis. 2016; 16:736.

17. Habib AG, Tambyah PA. Community-Acquired Klebsiella pneumoniae Central Nervous System Infections in Adults in Singapore. Eur J Clin Microbiol Infect Dis. 2003;22(8):486-8.

18. Chang WN, Huang CR, Lu CH, Chien CC. Adult Klebsiella pneumoniae Meningitis in Taiwan: An Overview. Acta Neurol Taiwan. 2012;21(2):87-96.

19. Teckie G, Karstaedt A. Spontaneous adult gram-negative bacillary meningitis in Soweto, South Africa. Int J Infect Dis. 2015;30:38-40.

20. Siu LK, Yeh K-M, Lin J-C, Fung C-P, Chang F-Y. Klebsiella pneumoniae liver abscess: a new invasive syndrome. Lancet Infect Dis. 2012;12:881-7.

21. Boglione L, Spezia C, Lipani F, Balbiano R, Canta F, Marrone R, et al. Klebsiella pneumoniae meningitis in a 38-year-old Chinese traveller with impaired glucose tolerance: a new emerging syndrome? Travel Med Infect Dis. 2008:6:32-5.

22. Tuon FF, Rocha JL, Arend LN, Pilonetto M, Wallbach K, Zanin HA. Treatment and outcome of nine cases of KPC-producing Klebsiella pneumoniae meningitis. Br Infect Assoc. 2013;4:161-4.

23. Yanagawa T, Nakamura H, Takei I, Maruyama H, Kataoka K, Saruta T, Kobayashi Y. Klebsiella pneumoniae meningitis associated with liver abscess: a case report. Jpn J Antibiot. 1989;42(10):2135-40.

24. Ohmori S, Shiraki K, Ito K, Inoue H, Ito T, Sakai T, et al. Septic endophthalmitis and meningitis associated with Klebsiella pneumoniae liver abscess. Hepatol Res. 2002;22(4):307-12.

25. Giobbia M, Scotton PG, Carniato A, Cruciani M, Farnia A, Daniotti E, et al. Community-acquired KZebsieUa pneumoniae bacteremia with meningitis and endophthalmitis in Italy. Int J Infect Dis. 2003;7:234-5.

26. Shih $\mathrm{H}-\mathrm{I}$, Lee $\mathrm{H}-\mathrm{C}$, Chuang $\mathrm{C}-\mathrm{H}, \mathrm{Ko}$ W-C. Fatal Klebsiella pneumoniae and Emphysematous Brain Abscess After Endoscopic Variceal Ligation in a Patient with Liver Cirrhosis and Diabetes Mellitus. J Formos Med Assoc. 2006;105:857-60.

27. Saccente M. Klebsiella pneumoniae liver abscess, Endophthalmitis, and meningitis in a man with newly recognized diabetes mellitus. Clin Infect Dis. 1999:29:1570-1.
28. Hsieh HF, Chen TW, Yu CY, Wang NC, Chu HC, Shih ML, et al. Aggressive hepatic resection for patients with pyogenic liver abscess and APACHE II score $>$ or $=15$. Am J Surg. 2008;196:346-50.

29. Tan J, Kan J, Qiu G, Zhao D, Ren F, Luo Z, et al. Clinical prognosis in neonatal bacterial meningitis: the role of cerebrospinal fluid protein. PLoS One. 2015;10:1-9.

30. Lin M-C, Chi H, Chiu N-C, Huang F-Y, Ho C-S. Factors for poor prognosis of neonatal bacterial meningitis in a medical center in northern Taiwan. J Microbiol Immunol. 2012;45:442-7.

31. Peng $H-L, H u Y, C$ Chen $H-J$, Song P-P, Jiang L. Risk factors for poor prognosis in children with refractory purulent meningitis and the discharge criteria. J Infect Public Health. 2018;11:238-42.

32. Shimohata T, Yanagawa K, Tanaka K, Nishizawa M. Clinical features of poorprognosis patients with adult bacterial meningitis. Clin Neurol. 2010;50:13740.

33. Yu VL, Hansen DS, Ko WC, Sagnimeni A, Klugman KP, von Gottberg Herman Goossens A, et al. Virulence characteristics of Klebsiella and clinical manifestations of K. pneumoniae bloodstream infections. Emerg Infect Dis. 2007:7:986-93.

34. Lin YT, Cheng YH, Chuang C, Chou SH, Liu WH, Huang CH, Yang TC, Kreiswirth BN, Chen L. Molecular and clinical characterization of multidrugresistant and Hypervirulent Klebsiella pneumoniae strains from liver abscess in Taiwan. Antimicrob Agents Chemother. 2020;64(5):e00174-20.

\section{Publisher's Note}

Springer Nature remains neutral with regard to jurisdictional claims in published maps and institutional affiliations.
Ready to submit your research? Choose BMC and benefit from:

- fast, convenient online submission

- thorough peer review by experienced researchers in your field

- rapid publication on acceptance

- support for research data, including large and complex data types

- gold Open Access which fosters wider collaboration and increased citations

- maximum visibility for your research: over $100 \mathrm{M}$ website views per year

At BMC, research is always in progress.

Learn more biomedcentral.com/submissions 